\title{
HUBUNGAN PERILAKU MEROKOK TERHADAP KEBERHASILAN PENGOBATAN PADA PASIEN TUBERKULOSIS DI PUSKESMAS KECAMATAN JOHAR BARU, JAKARTA PUSAT TAHUN 2016
}

\author{
Winda Afdilla.J' ${ }^{1}$ Insan Sosiawan A. Tunru ${ }^{2}$ Yusnita $^{3}$ \\ ${ }^{1}$ Fakultas Kedokteran Universitas YARSI \\ Email: windaafdilla@yahoo.co.id \\ ${ }^{2}$ Bagian Patologi Anatomi Fakultas Kedokteran Universitas YARSI \\ ${ }^{3}$ Bagian Ilmu Kesehatan Masyarakat Fakultas Kedokteran Universitas YARSI
}

\begin{abstract}
ABSTRAK
Tuberkulosis (TB) merupakan penyakit menular yang menjadi salah satu ancaman utama bagi manusia, Untuk menangani segala ancaman dari tuberkulosis maka WHO telah mengembangkan strategi penanggulangan TB yang dikenal sebagai strategi DOTS untuk meningkatkan keberhasilan pengobatan TB dengan indikator yang digunakan adalah sembuh dan pengobatan lengkap. Keberhasilan pengobatan dipengaruhi oleh faktor internal dan eksternal salah satu contohnya merokok. Penelitian ini bertujuan untuk mengetahui hubungan perilaku merokok terhadap keberhasilan pengobatan pada pasien tuberculosis di Puskesmas Kecamatan Johar Baru Jakarta Pusat tahun 2016. Penelitian ini dilakukan dengan metode kuantitatif non-eksperimental secara cross sectional. Populasi dan sampel adalah pasien tuberkulosis dewasa yang terdaftar di Puskesmas Kecamatan Johar Baru Jakarta Pusat tahun 2016. Penetapan sampel dengan menggunakan Simple Random Sampling. Pengambilan data dilakukan dengan cara wawancara menggunakan kuesioner. Analisis data mengunakan SPSS dengan uji ChiSquare. Terdapat 45 orang $(80,4 \%)$ berhasil dalam pengobtan tuberculosis dengan 25 orang $(83,9 \%)$ responden yang tidak merokok. Dari hasil uji statistik menggunakan uji Chi-Square didapatkan nilai P $=0,69$. Tidak ada hubungan perilaku merokok terhadap keberhasilan pengobatan Tuberkulosis di Puskesmas Kecamatan Johar Baru Jakarta Pusat tahun 2016.
\end{abstract}

Kata Kunci : Perilaku Merokok, Keberhasilan Pengobatan Tuberkulosi

\begin{abstract}
Tuberculosis $(T B)$ is an infectious disease that poses one of the major threats to humans. To deal with all threats from tuberculosis, WHO has developed a TB control strategy known as the DOTS strategy to improve the success of TB treatment with the indicator used being cured and complete treatment. The success of treatment is influenced by internal and external factors such as smoking. This study aims to determine the relationship of smoking behavior with the success of tuberculosis treatment at community health center of Johar Baru Central Jakarta in 2016. This research was conducted by CrossSectional non-experimental quantitative method. Population and sample are adult tuberculosis patients registered at community health center of Johar Baru Central Jakarta in 2016. Samples are selected by using Simple Random Sampling. The data were collected by interview using questionnaire. Data analysis using SPSS with Chi-Square test. There were 45 respondents $(80,4 \%)$ succeed in tuberculosis treatment with 25 people $(83,9 \%)$ of respondents who did not smoke. Results of statistical tests using Chi-Square test obtained value $P=0.69(>0,05)$. Conclusions: There is no relation between smoking behavior with the success of tuberculosis treatment at community health center of Johar Baru Central Jakarta in 2016.
\end{abstract}

Keywords: Smoking Behavior, Success of Tuberculosis Treatment 


\section{Pendahuluan}

Tuberkulosis(TB) merupakan penyakit menular yang disebabkan oleh bakteri berbentuk basil gram positif Mycobacterium tuberculosis, yang cara penularannya melalui kontak dengan Batang Tahan Asam (BTA) positif atau droplet (batuk atau bersin) orang yang terinfeksi bakteri ini ${ }^{5}$.

Berdasarkan data dari "World Health Statistic 2013" menunjukkan tingginya angka prevalensi tuberkulosis per 100.000 penduduk di beberapa negara ASEAN dan SEAR, dan tahun 1992 World Health Organization (WHO) telah mencanangkan tuberkulosis sebagai "Global Emergency" 2. Jumlah penderita penyakit TB di Indonesia menduduki peringkat ketiga terbesar setelah India dan China, dengan angka kematian sebesar 175.000 per tahun dan kasus baru 450.000 per tahun. Pada setiap 100.000 penduduk ada 125 penderita tuberkulosis yang menular ${ }^{3}$.

Sejak tahun 1995, WHO dan International Union Agains Tuberculosis and Lung Disease (IUATLD) telah mengembangkan strategi penanggulangan TB yang dikenal sebagai strategi Directly Observed Treatment Shortcourse chemotherapy (DOTS). Penerapan strategi DOTS secara baik dapat cepat menekan penularan, mencegah berkembangnya TB-
MDR serta meningkatkan keberhasilan pengobatan TB paru ${ }^{2}$.

Indikator yang digunakan dalam keberhasilan pengobatan tuberkulosis adalah sembuh dan pengobatan lengkap. Angka keberhasilan pengobatan $\mathrm{TB}$ di Indonesia tahun 2015 sebesar 84\%, dengan pencapaian tertinggi sebesar $93 \%$ di Sulawesi Utara sedangkan pencapaina terendah sebesar $37 \%$ di Provinsi Kalimantan Tengah 4. Menurut Nainggolan $(2013)^{7}$ terdapat dua faktor yang mempengaruhi keberhasilan pengobatan pada pasien TB yaitu faktor internal dan eksternal. Faktor internal meliputi karakteristik dan perilaku pasien itu sendiri, seperti umur, pendidikan, perilaku merokok, berikutnya faktor eksternal meliputi faktor lingkungan dan sosial yang berada disekitar pasien, seperti kondisi rumah, peran pengawas PMO, kepatuhan minum obat dan lain-lain.

Prevalensi perokok di Indonesia sangat tinggi di berbagai lapisan masyarakat, mulai dari anak-anak, remaja, dan dewasa. Data Survei Sosial Ekonomi Nasional (susens) dan Riskedes menunjukkan bahwa prevalensi merokok untuk semua kelompok umur mengalami lonjakan. Hamper $80 \%$ perokok mulai merokok ketika usianya belum mencapai 19 tahun $^{2}$. 
Kebiasaan merokok akan merusak mekanisme pertahanan paru. Selain itu, pajanan asap rokok akan meningkatkan airway resistence dan permeabilitas epitel paru-paru, juga merusak gerak silia. Asap rokok dapat merusak makrofag dan menurunkan respon terhadap antigen, meningkatkan sintesis elastase, kemudian menurunkan produksi antiprotease ${ }^{1}$.

Islam mengajarkan tentang kesehatan. Kesehatan merupakan suatu keadaan yang sangat penting untuk kelangsungan hidup dan kebugaran tubuh. Kesehatan merupakan nikmat Allah SWT yang terbesar bagi hamba-Nya setelah nikmat Iman dan Islam. Menjaga kesehatan merupakan bagian dari ibadah, karena kesempatan beribadah dipengaruhi oleh kesehatan ${ }^{9}$.

Tubuh kita pada dasarnya adalah amanah dari Allah yang harus dijaga, tapi dengan rokok dapat menimbulkan bahaya bagi tubuh, salah satunya adalah penyakit Tuberkulosis dan sebagai makhluk ciptaan Allah kita wajib untuk berobat karena pada dasarnya semua penyakit berasal dari Allah, maka yang dapat menyembuhkan juga hanya Allah. Akan tetapi untuk mencapai kesembuhan tersebut tentunya dengan usaha yang maksimal. Sesungguhnya Allah mendatangkan penyakit, maka bersama dengan itu Allah juga mendatangkan obat.
Menurut Sigit (2011) menyatakan bahwa ada hubungan antara kebiasaan merokok terhadap keberhasilan pengobatan TB paru dengan strategi DOTS dapat diketahui nilai $\mathrm{p}=0,000$, sehingga didapatkan responden yang merokok memiliki risiko 38,5 kali lebih besar untuk gagal pengobatan dibandingkan dengan pasien yang tidak memiliki kebiasaan merokok.

Sedangkan berdasarkan penelitian $\operatorname{Tirtana}^{8}$ responden yang memiliki kebiasaan tidak merokok sebanyak $71,1 \%$, dimana merokok sebanyak 28,9\%. Sehingga didapatkan rokok tidak berpengaruh terhadap keberhasilan pengoatan pada pasien TB.

\section{Metode Penelitian}

Penelitian ini merupakan penelitian kuantitatif non-eksperimental atau bersifat analitik cross sectional. Populasi dan sampel adalah semua pasien tuberkolosis yang terdaftar di Puskesmas Kecamatan Johar Baru, Jakarta pusat tahun 2016 sebanyak 125 orang. Sampel dipilih dengan menggunakan metode simple random sampling dan didapatkan jumlah sampel 56 orang. Responden pada penelitian ini merupakan orang dewasa yang memenuhi kriteria inklusi dan kriteria eksklusi. Kriteria inklusi pada penelitian ini adalah usia pasien $>15$ tahun, telah menyelesaikan pengobatan OAT selama 6 bulan pada tahun 
2016, pasien yang bersedia dan telah menanda tangani informed consent serta alamat yang dapat dijangkau peneliti. Untuk Kriteria eksklusi yaitu Pasien TB tidak bersedia mengikuti penelitian

Pengumpulan data dilakukan dengan data sekunder (TB03) yang dan membagikan kuesioner kepada pendertita tuberkulosis di puskesmas johar baru. Analisis bivariat dalam penelitian ini menggunakan uji Chi Square dengan SPSS 23.0 for windows.

\section{Hasil}

Pada tabel 4.1 terlihat bahwa mayoritas responden berjenis kelamin lakilaki sebanyak 30 orang $(53,6 \%)$ dengan usia terbanyak $>40$ tahun yaitu 26 orang $(46,4 \%)$. Berdasarkan pendidikan responden sebagian besar SMA dan SD yaitu 18 orang $(32,1 \%)$ dan Responden yang bekerja dan tidak bekerja jumlahnya sama yaitu 28 orang $(50 \%)$

Pada tabel 4.2 terlihat bahwa pasien tuberkulosis yang tidak merokok yaitu 32 orang $(57,1) \%, 14$ orang $(58,3 \%)$ diantaranya dikategorikan sebagai perokok ringan. Hal yang sama juga dapat dilihat pada pengobatan pada pasien tuberkulosis yaitu 45 orang $(80,4 \%)$

berhasil. Dari hasil uji statistik menggunakan uji Chi-Square didapatkan nilai $\mathrm{P}>0,05$ yaitu 0,69 . Hal ini memperlihatkan bahwa tidak ada hubungan antara perilaku merokok dengan keberhasilan

$$
\text { pengobatan pada pasien }
$$

Tuberkulosis di Puskesmas Kecamatan Johar Baru Jakarta Pusat tahun 2016.

\section{Tabel 4.1 Karakteristik Responden}

\begin{tabular}{|c|c|c|}
\hline Variabel & Jumlah & $\begin{array}{c}\text { Persentase } \\
(\%)\end{array}$ \\
\hline \multicolumn{3}{|l|}{ Jenis Kelamin } \\
\hline Laki-Laki & 30 & 53,6 \\
\hline Perempuan & 26 & 46,4 \\
\hline Subtotal & 56 & 100 \\
\hline \multicolumn{3}{|l|}{ Umur } \\
\hline$<40 \mathrm{Th}$ & 29 & 51,8 \\
\hline$>40 \mathrm{Th}$ & 27 & 48,2 \\
\hline Subtotal & 56 & 100 \\
\hline \multicolumn{3}{|l|}{ Pendidikan } \\
\hline \multicolumn{3}{|l|}{ Terakhir } \\
\hline Tidak Tamat SD & 3 & 5,4 \\
\hline $\mathrm{SD}$ & 18 & 32,1 \\
\hline SMP & 13 & 23,2 \\
\hline SMA & 18 & 32,1 \\
\hline Akademi/ & 4 & 7,1 \\
\hline \multicolumn{3}{|l|}{ Sarjana } \\
\hline Subtotal & 56 & 100 \\
\hline \multicolumn{3}{|l|}{ Pekerjaan } \\
\hline Bekerja & 28 & 50 \\
\hline Tidak Bekerja & 28 & 50 \\
\hline Subtotal & 56 & 100 \\
\hline
\end{tabular}


Tabel 4.2 Hubungan Jumlah Kunjungan Balita Ke Posyandu dengan Status Gizi Balita Di Kelurahan Cakung Barat Jakarta Timur Tahun 2017

\begin{tabular}{cccccc}
\hline \multirow{2}{*}{ Perilaku Merokok } & \multicolumn{2}{c}{ Peberhasilan } & Total & P \\
& & Berhasil & Tidak & & \\
& & Berhasil & & \\
\hline Merokok & Jumlah & 20 & 5 & 25 & 0,69 \\
& $\%$ & 76,0 & 24,0 & 100 & \\
Tidak & Jumlah & 25 & 6 & 31 & \\
Merokok & $\%$ & 83,9 & 16,1 & 100 & \\
\hline
\end{tabular}

\section{Pembahasan}

Pada penelitian ini

keberhasilan pengobatan dilihat dari indikator yaitu, pasien yang sembuh dan pengobatan lengkap yang dibagi menjadi dua kategori yaitu, berhasil dan tidak berhasil. Untuk perilaku merokok pada pasien tuberkulosis dikatakan merokok apablia tidak pernah menghisap rokok walaupun sekali hisap, dari yang merokok juga dapat dibagi menjadi tiga kategori berdasarkan jumlah rokok yang dihisap yaitu perokok ringan apabila menghisap <10 batang perhari, perook sedang apabila menghisap 1020 batang perhari dan perokok berat yang menghisap rokok >20 batang perhari.
Hasil pada penelitian ini sama seperti penelitian Pratiwi (2012) juga mengatakan bahwa tidak ada hubungan antara kebiasaan merokok dengan keberhasilan pengobatan $(\mathrm{p}=0,984)$, hal tersebut terjadi karena sebanyak 47,5\% responden adalah berjenis kelamin perempuan sehingga memiliki riwayat bukan perokok yang juga sejalan dengan penelitian Tirtana (2011) yang menyatakan bahwa, merokok bukan merupakan penyebab tuberkulosis tetapi pendukung untuk lebih berat penyakit tuberkulosisnya. Penelitian Berin (2011) yang menyatakan bahwa pengobatan pasien tuberkulosis yang memiliki kebiasaan merokok didapatkan lebih banyak yang gagal dibandingkan yang sembuh $\mathrm{P}=0,42$.

Pada penelitian ini terdapat beberapa Keterbatasan penelitian ini 
antara lain sulitnya menemukan alamat responden karena tempat tinggal di pemukiman padat penduduk ataupun ada alamat yang pindah. Kemudian setelah menemukan alamat, ada beberapa responden yang tidak ada di rumah ataupun bekerja.

\section{Simpulan}

Berdasarkan hasil penelitian ini, tidak ada hubungan antara perilaku merokok dengan keberhasilan pengobatan pada pasien Tuberkulosis di Puskesmas Kecamata Johar Baru Jakarta Pusat tahun 2016 Saran

Bagi instansi kesehatan, diharapkan terus adanya peningkatan mutu dan kualitas pelayanan kesehatan khusunya dalam perbaikan sarana dan prasarana serta petugas kesehatan yang menangani tuberkulosis Bagi responden, selalu menjaga kesehatan tubuh dan kesehtan lingkungan sekitar tempat tinggal, selalu rutin memeriksakan dirinya ke puskesmas untuk mencegah agar tidak terserang penyakit dan sebaiknya Bagi peneliti selanjutnya, apabila memiliki kecukupan dana dan waktu sebaiknya jumlah sampel lebih diperbanyak dan cakupan wilayah lebih luas tidak hanya disatu kecamatan.

\section{Daftar Pustaka}

1. Aditama,TY. Rokok dan Tuberkulosis Paru. Medika. No 5 Th. XIX, pp: 327-326-323 ; 2003

2. Department Kesehatan RI 2013. Perilaku Merokok Masyarakat Indonesia.http://www.depkes.go. $\mathrm{id} /$ resources/download/pusdatin/i nfodatin/infodatin-hari-tanpatembakau-sedunia.pdf. Diakses tanggal 1 April 2017.

3. Departement Kesehatan RI 2014. Pedoman Nasional Penanggulangan Tuberkulosis. http://spiritia.or.id/dokumen/ped oman-tbnasional2014.pdf.

Diakses tanggal 1 April 2017

4. Departement Kesehatan RI 2015. Profil Kesehatan Indonesia 2014.

http://www.depkes.go.id/resourc es/download/pusdatin/profilkesehatan-indonesia/profilkesehatan-indonesia-2014.pdf. Diakses tanggal 9 April 2017

5. Departement Kesehatan RI 2015. Tuberkulosis: Temukan dan Obati Sampai Sembuh. http://www.depkes.go.id/resourc es/download/pusdatin/infodatin/i 
nfodatin_tb.pdf. Diakses tanggal

10 November 2016

6. Lin, H. 2007. Harvard School of

Public Health. Available from:http://cybermed.cbn.net.id/ cbprtl/cybermed/detail.aspx $? \mathrm{x}=$ Health+News\&y=cybermed $|0| 0 \mid$ $5 \mid 4438$. Diakses pada tanggal 12 April 2017.

7. Nainggolan, Helena RN. Faktor yang Berhubungan Dengan Gagal Konvers pasien TB Paru kategori I Pada Akhir Pengobatan Fase Intensif di Kota Medan, Tesis, Universitas Sumatera Utara, Medan; 2013

8. Tirtana, Bertin Tanggap. FaktorFaktor yang mempengaruhi keberhasilan pengobatan pada pasien TB Paru dengan Resistensi Obat TBC DI Wilayang Jateng. Semarang: FK.

UNDIP; 2011 